\title{
The Role of Granular Cushion in Load Sharing of Unconnected Piled Rafts in Clayey Soils
}

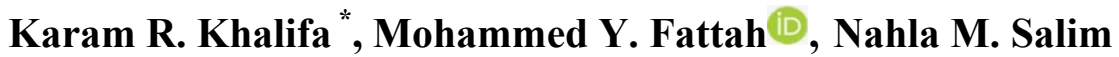 \\ Civil Engineering Dept., University of Technology-Iraq, Alsina'a street, 10066 Baghdad, Iraq. \\ *Corresponding author Email: bce.19.65@grad.uotechnology.edu.iq
}

\section{H I G H L I G H T S}

- The load sharing capability of the system was investigated using PLAXIS finite element analysis.

- The impact of cushion thickness on settlement reductions was investigated.

- The pile head has the greatest axial stress in the connecting piled raft system., and then decreases along the length.

- The unconnected head's maximum axial load is transferred down to a point a certain distance below the pile head.

- As the cushion layer thickness increases, the axial stress at the pile head decreases.

\section{A R T I C L E I N F O}

\begin{tabular}{l}
\hline Handling editor: Wasan I. Khalil \\
\hline Keywords: \\
Piled raft \\
Cushion \\
Disconnected \\
Soft clay \\
Finite elements \\
\hline
\end{tabular}

\begin{abstract}
A B S T R A C T
Over the past few decades, interest has grown about the role of the piled raft structure in soils. A structural fill cushion separates the piles from the raft in the form of an unconnected piled raft base (UCPRF). Given the advantage of this structure, the load is dispersed between the raft and the piles by the cushion. The cushion serves as a load redistributor between the raft and the piles. Load dispersion capability of the system was theoretically estimated using PLAXIS finite element analysis software in this study. The effect of cushion thickness on settlement reductions was investigated as well. Obtained results showed that the pile head has the greatest axial stress in the piled raft system., however decreased along the length of the pile according to finite element analysis. The unconnected head's maximum axial load is transferred down to a point a certain distance below the pile head (approximately two meters in the studied model). Above the top two meters, the axial stress in the pile begins to decrease, following the same pattern as the connected system. The thickness of the cushion affects the load sharing between the cushion and the piles. As the cushion thickness increases, the axial stress at the pile head decreases.
\end{abstract}

\section{Introduction}

Structural rafts are used for supporting structures and construction in general. If the shallow conditions of the subsoil (unsafe loading or unstable settlements) are unfavorable, then the piles are used to redistribute the entire load to more suitable soil layers. Settlements, both total and individual, are usually deciding factors in the selection of piled raft foundations. The three load-bearing components of the piled raft base are piles, raft, and subsoil. The total load transferred from the building to the soil surface and connected piles are distributed by the raft according to their relative stiffness. Traditionally, the piles were assumed to support the overall load in the design of piled foundations. The contribution of the raft is taken into account in piled raft foundation systems to verify the ultimate bearing capacity and usability of the overall system. Burland et al. [1] were the first to suggest the use of piles to lower raft settlement by placing one pile under each column of a construction. Using a finite element approach, Zhuang and Lee [2] investigated load-carrying between the piles and the raft. In a piled raft system, they found that pile stiffness, raft rigidity, and pile length to width ratio all had an impact on load sharing around piles.

After years of completing the construction of any building over the base, the settlement of the piled raft can be measured. Fattah et al. [3] investigated the consolidation settlement of piled rafts over clayey soils using the finite element technique, detecting the dissipation of excess pore water pressure and its effect on the bearing capacity of piled raft foundations. The settlement of the stacked raft can be computed even after years of completing the construction of any building over the foundation. Furthermore, the finite element method was used to calculate the consolidation settlement of piled rafts over clayey 
soils and to detect the dissipation of excess pore water pressure and its effect on piled raft foundation bearing capability. The settlement beneath the piled raft base caused by the dissipation of excess pore water pressure was discovered to have a significant impact on the foundation's final settlement, and sufficient attention should be paid to settlement variance over time. The number of piles in a group determines the average load borne by each. The pile groups $(2 \times 1,3 \times 1,2 \times 2,3 \times 2$, and $3 \times 3)$ were found to hold around $24 \%, 32 \%, 42 \%, 58 \%$, and 79 percent of the total vertical load, respectively. With the raft thickness, the load distribution between piles becomes more uniform.

Fattah et al. [4] found from finite element analysis that the distribution of load between piles becomes more uniform with the increase of raft thickness. For an unpiled raft with high stiffness, the pile may share the same amount of load. Increasing the pile diameter leads to decreasing the pore water pressure under the raft, reducing the settlement of the raft and changing the shape of moment distribution in the raft as well as increasing the pile's share of the load. Spacing between piles affects directly the pile-soil interaction.

In a conventional pile-raft system, the piles are attached to the raft and extend down into competent soil at depth. In a conventional pile-raft system, the piles are connected to the raft and extend into competent soil at depths. While these piles are effective at reducing raft settling, they can cause substantial shear forces and bending moments, which could undermine the raft's structural design. Cao et al. [5] and Wong et al. [6] proposed that the piles be separated from the raft and treated as subsoil enhancement rather than structural components to avoid problems with high stresses in the piles and raft. A cushion of structural fill material may also be used to fill the gap between the raft and the disconnected piles. Also, they proposed that the piles be separated from the raft and treated as subsoil reinforcement rather than structural members to solve problems with high stresses in the piles and raft. A cushion of structural fill material may also be used to fill the gap between the raft and the unconnected piles. The cushion, which is made up of a sand-gravel mixture compressed in the layer between the raft and head of piles, according to Liang et al. [7], plays an important role in organizing the bearing capacity of the subsoil and changing the load transfer mechanisms of piles. Since then, it has been described by many authors, [8,9,10]. According to reference [9], in sandy soil, the behavior of a disconnected piled raft foundation was investigated using a numerical model and 3D Finite Element analysis via ABAQUS software. The effect of cushion thickness and stiffness, pile length, foundation soil stiffness, and bearing soil stiffness on the performance of the unconnected piled raft was investigated in this report. The results of this study revealed that when the cushion thickness and stiffness are increased, the foundation system's settlement is reduced further. Karim et al. [11] found that the percentage of the load carried by piles to the total applied load of the numerical model for case sixteen piles with raft is around $42 \%$. The contribution to carry the load of piles relative to the total load is decrease with the increase of the spacing to diameter ratio. The percentage of the load carrying for piled raft for the case of two piles with raft only decreases about 23\% when the spacing between piles increases from 3 to 10 times pile diameters. Alhassani et al. [12] carried out numerical analysis to investigate the effect of thickness and stiffness of the cushion, pile length, stiffness of foundation soil, and stiffness of bearing soil on the performance of the unconnected piled raft. The results indicated that when unconnected piles are used, the axial stress along the pile is significantly reduced e.g. the axial stress at the head of the unconnected pile is decreased by $37.8 \%$ compared with that related to the connected pile. It was also found that the stiffness and thickness of the cushion and stiffness of foundation soil have a considerable role in the reduction of the settlement.

The objective of the present study is to investigate the effect of compacted granular cushion above the pile group in load transfer and distribution of stresses in unconnected piled raft foundations embedded in clayey soil.

\section{Methodology and model}

A three-dimensional finite element commercial program (PLAXIS) is used in the analysis. The reference model for this parametric analysis is made up of the following components:

- $\quad \operatorname{Raft}(12 * 12) \mathrm{m}, 0.8$ depth.

- A (6 x 6) piles group of $0.5 \mathrm{~m}$ in diameter and $12 \mathrm{~m}$ in length, spaced at $2 \mathrm{~m}(4 \mathrm{D})$.

- Cushion layer of a thickness (1) m.

- Uniform surcharge load applied on the rafts of $100 \mathrm{kPa}$.

PLAXIS 3D has the benefit of allowing to examine a quarter of the piled raft base. This benefit was considered, and only one-fourth of the geometry was used to simulate the piled raft . To minimize the influence of the boundaries on the foundation displacement, the domain of the soil continuum used in this study is extended to a wide distance. The soil mass is 20 meters long (in the x-direction), 20 meters wide (in the y-direction), and 20 meters tall (in the z-direction).

Table 1 summarizes the soil characteristics. Rafts and piles are modelled as elastic materials in the study. A soft soil model is used to simulate the soil's nonlinear behavior. As a distributed load, a vertical pressure of $100 \mathrm{kPa}$ is applied to the raft. The cushion, which is made up of layers of coarse-grained material, is schematically represented in Fig. 1. The unconnected structure, which includes the raft, soil, and piles, is visualized in Fig 2. 


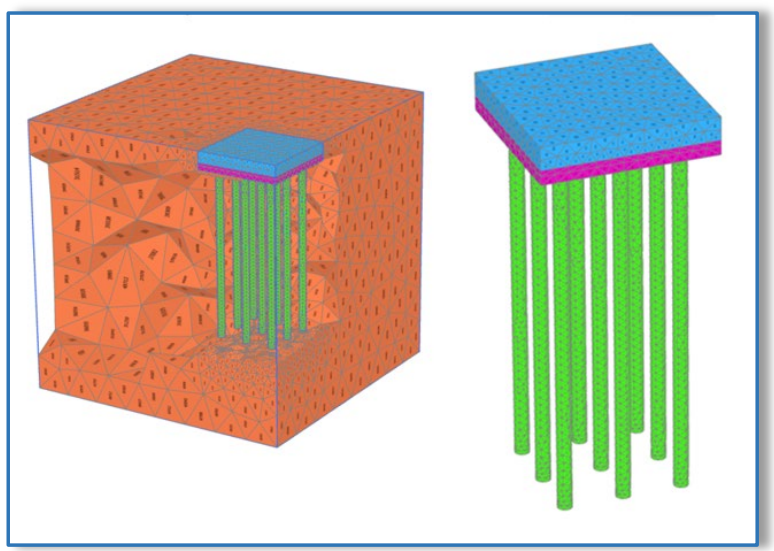

Figure 1: iFnite element mesh of the unconnected piled raft foundation

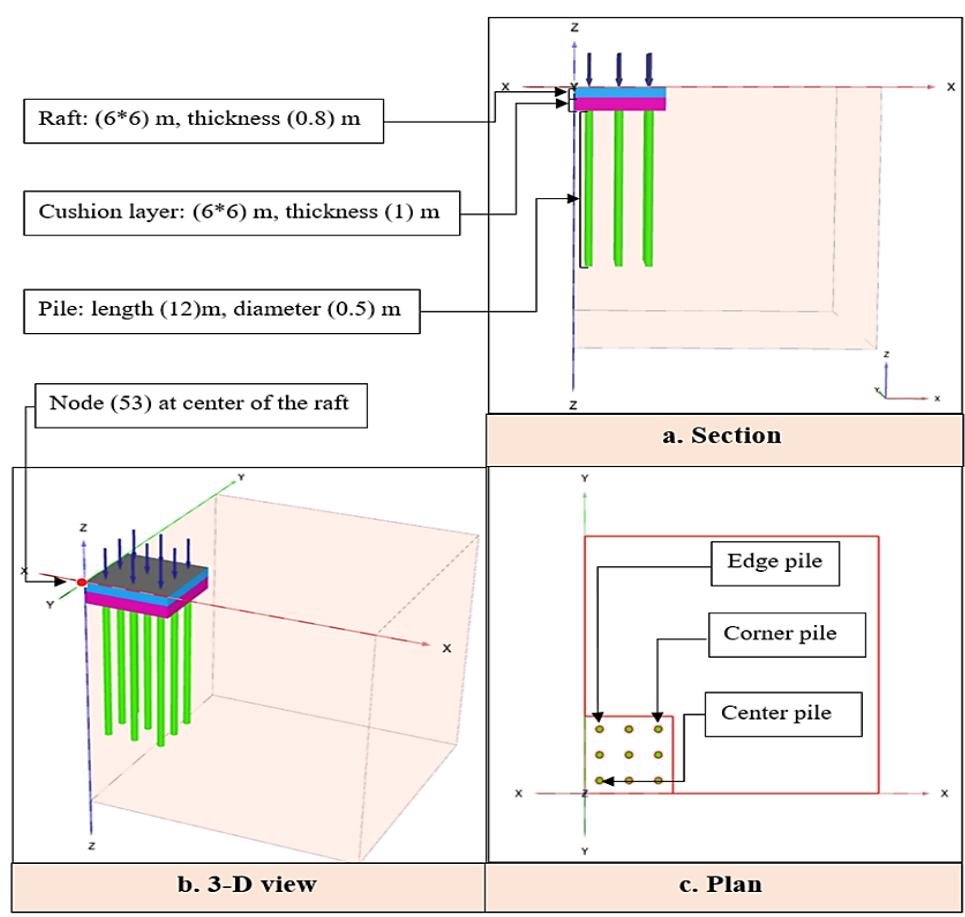

Figure 2: One-fourth of the reference piled raft system

Table 1: The parameters of the soil and piled raft used in the analysis.

\begin{tabular}{|c|c|c|c|}
\hline & Foundation soil (clay) & Subbase (Cushion) & $\begin{array}{l}\text { Concrete } \\
\text { (Piles and raft) }\end{array}$ \\
\hline Model & Soft soil & Mohr-Coulomb & Linear elastic \\
\hline $\begin{array}{l}\text { Unit weight } \\
\boldsymbol{\gamma}\left(\mathrm{kN} / \mathrm{m}^{3}\right)\end{array}$ & 17.1 & 22.06 & $24 * *$ \\
\hline $\begin{array}{l}\text { Modulus of elasticity } \\
\mathrm{E}^{\prime}\left(\mathrm{kN} / \mathrm{m}^{2}\right)\end{array}$ & ----- & 120000 & $37000000 * *$ \\
\hline $\begin{array}{l}\text { Angle of friction } \\
\phi^{\prime}\left({ }^{\circ}\right)\end{array}$ & 1 & 40 & ----- \\
\hline Dilatancy angle $\boldsymbol{\psi}\left(^{\circ}\right)$ & ----- & 10 & ----- \\
\hline Poisson's ratio & ----- & 0.35 & 0.2 \\
\hline$\lambda *$ & 0.135 & ------ & ----- \\
\hline К* & 0.0123 & ------ & ----- \\
\hline $\mathrm{c}^{\prime}(\mathrm{kPa})$ & 15 & ------ & ----- \\
\hline
\end{tabular}

A cushion of compacted structural fill material fills the void between the raft and the piles. Under the raft, the cushion is used to redistribute vertical stresses between the piles and the surrounding soil. The analysis is carried out for a $0.8 \mathrm{~m}$ thick square raft with an area of $144 \mathrm{~m}^{2}$ supported on 36 unconnected piles spaced at $3.3 \mathrm{~d}$, each pile being $0.5 \mathrm{~m}$ in diameter and 12 
$\mathrm{m}$ in length, to compare the two cases of connected and unconnected structures. The cushion has a modulus of $120 \mathrm{MPa}$ and a thickness of $0.5 \mathrm{~m}$.

\section{Results and discussion}

The total settlement of a disconnected pile raft foundation, relative settlement of the raft foundation, axial load via the pile length, and pile load ratio are the most major steps of this study $\left(\alpha_{\mathrm{PR}}\right)$. A parameter used in the design of the piled raft base is the load sharing between the pile and the raft. The pile load ratio $\left(\alpha_{\mathrm{PR}}\right)$;

$$
\alpha P R=\Sigma \text { Ppile } / \text { Ptotal }
$$

where $\Sigma$ Ppile is the sum of loads at pile head and Ptotal is the total applied loads. The load distribution between the piles and the raft is defined by this parameter.

\subsection{The general effect of cushion}

The settlements of connected and unconnected piled raft systems are shown in Figure( 3 ). When compared to the traditional pile group model, the maximum settlement of the linked piled raft has decreased by $37 \%$, while the maximum settlement of the unconnected piled raft has decreased by 45 percent.

Figure (4) presents the displacement of soil around piles and rafts. Figure (5) depicts the relationship between axial pile stress and pile length for connected and unconnected systems. The axial stress along the pile length in the unconnected system is smaller than that in the connected system, as shown in the figure. In the connected system, the maximum axial stress occurs at the pile head and then reduces along the length of the pile. The maximum axial stress in the unconnected system is moved downwards to a length beyond the pile head (approximately two meters in the studied model). The load shared by the cushion allows the axial load in the top two meters of the pile head to reduce. The cushion's vertical load is then progressively shifted back to the lower sections of the pile by skin resistance. Similar to the well-known down drag phenomenon, the vertical load is transferred from the cushion to the pile. The axial load in the pile started to decline above the top two meters, following the same pattern as the connected system. Sharma et al. [10] defined a load transfer behavior for an unconnected piled raft system that is similar to this one.

\subsection{The impact of cushion thickness}

The study is for a $0.8 \mathrm{~m}$ thick square raft with a total area of $144 \mathrm{~m} 2$ and 36 unconnected piles supporting it. The thickness of the cushion ranges from 0.5 to $2 \mathrm{~m}$. The variation in total settlement versus cushion thickness is depicted in Figure (6) and Figure (7) illustrates the axial stress versus pile length for diverse cushion thickness values. The results indicate that as the cushion thickness increases, the total settlement of the raft reduces slightly, and the axial load rises along the pile length. It is also worth noting that the axial stress at the pile head reduces as cushion thickness increases. It is possible to conclude that the thickness of the cushion influences the load sharing between the cushion and the piles. The findings show that as the cushion thickness increases, the raft's total settlement decreases slightly while the axial load increases along pile length. It's also worth mentioning that as cushion thickness increases, the axial stress at the pile head decreases. It is possible to deduce that the cushion thickness affects the load distribution between the cushion and the piles.

The results are compatible with the experimental results obtained by Hadi et al. [13] who found that the load settlement curve for each of the model tests is seen to be nonlinear.

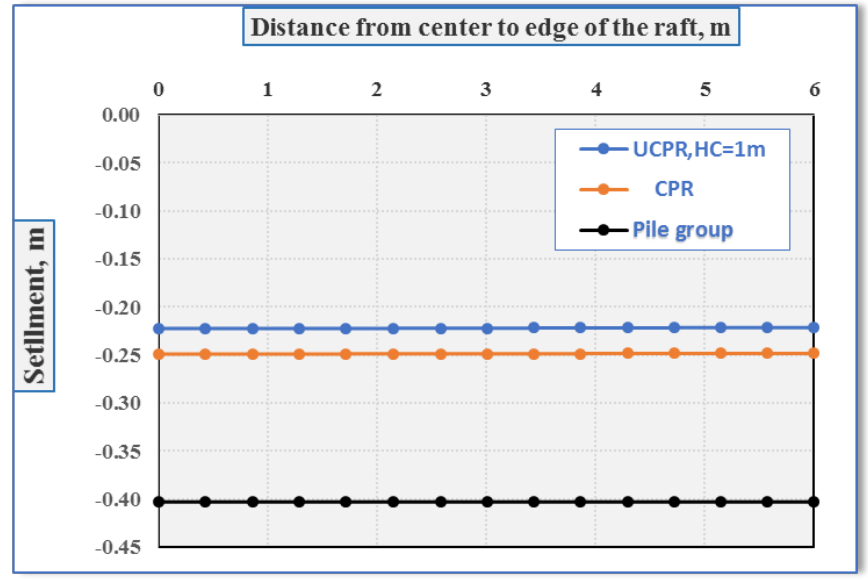

Figure 3: Settlement along the centreline of the raft, CPR, UCPR 


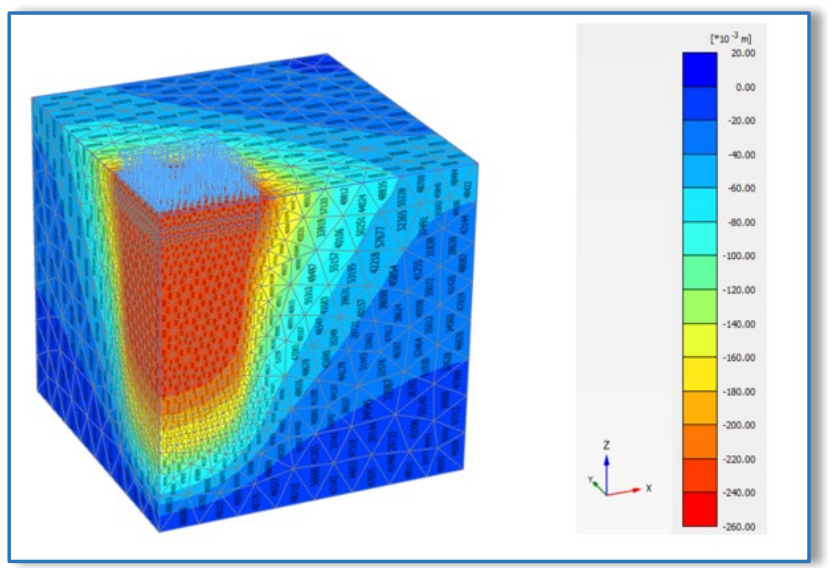

Figure 4: The settlement shading of piles and raft

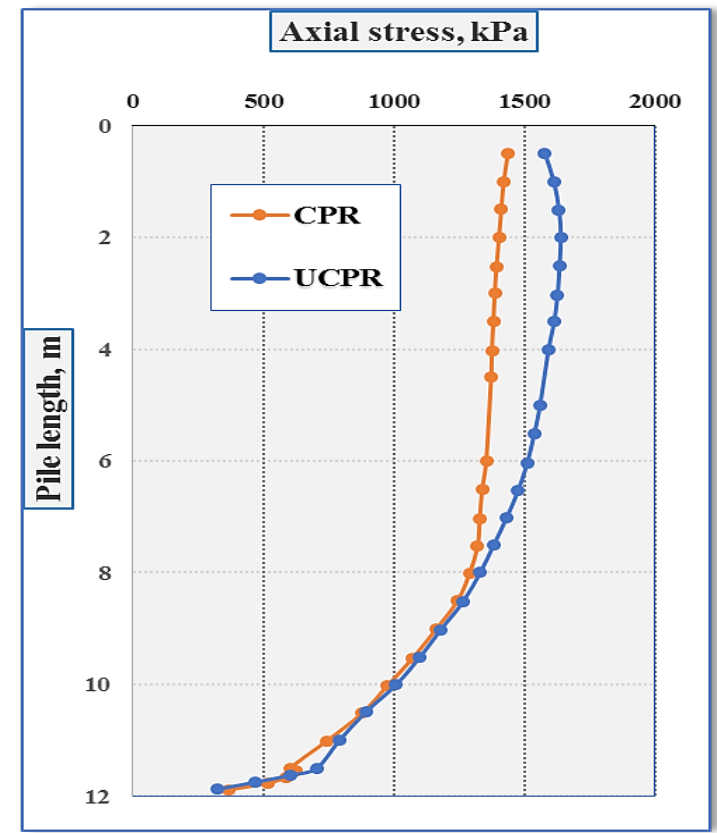

Figure 5: Variation of the axial stress along with the connected and unconnected centre piles

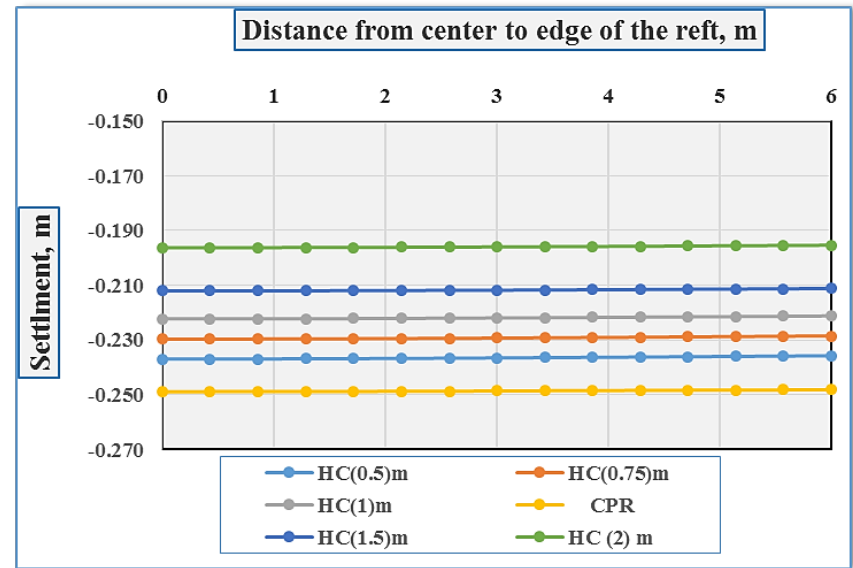

Figure 6: Variation of settlement along the centreline of the raft with the cushion thickness 


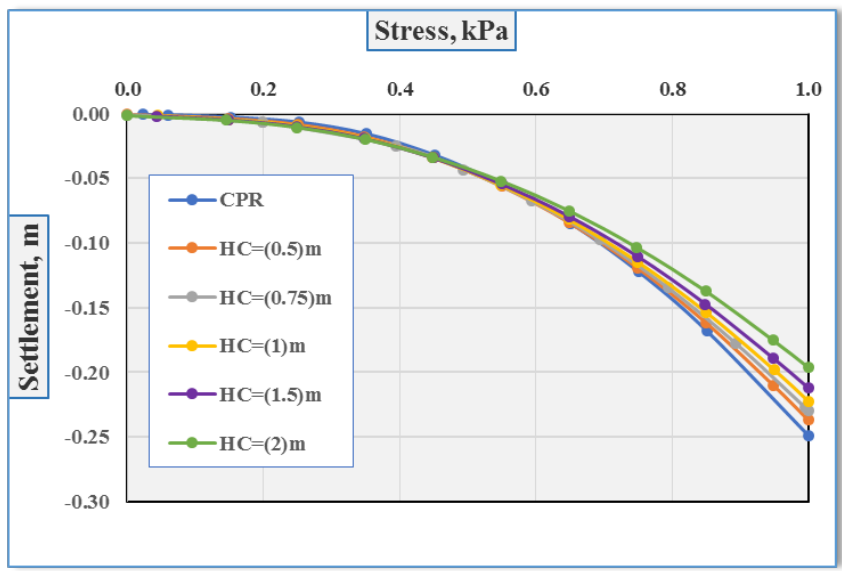

Figure 7: Variation of settlement in the center of the raft with the cushion thickness

Figures (8) and (9) show the variation of axial stress along with the center pile and raft for different values of the cushion thickness. As can be seen, increasing the cushion thickness has a minor effect on the axial stress along with the pile. As the pile load sharing ratio is related to the axial stress at the pile, the effect of the cushion thickness on this ratio is similar to that on the pile axial stress. This finding is clearly illustrated in Tables (2) and (3).

The analysis of results obtained by Mamood et al. [14] for the normal effective stress component showed that the maximum value is in the upper third part of the pile. The reason for concentrating stresses in that part is because the partially saturated soil has a maximum negative pore water pressure at the top of the soil surface which is a propagandist of concentrating effective stresses in that part of soil. Increasing effective stress leads to increasing the friction resistance at the pile surface and constrain the movement of the pile.

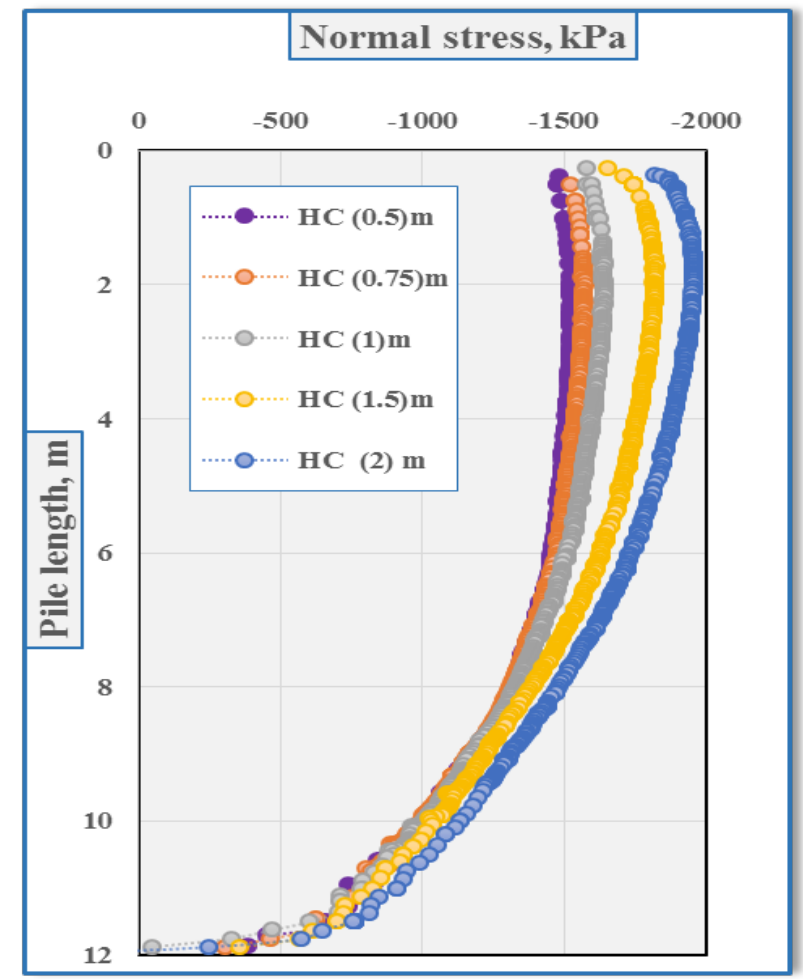

Figure 8: Variation of the axial stress along the centre piles with the cushion thickness 


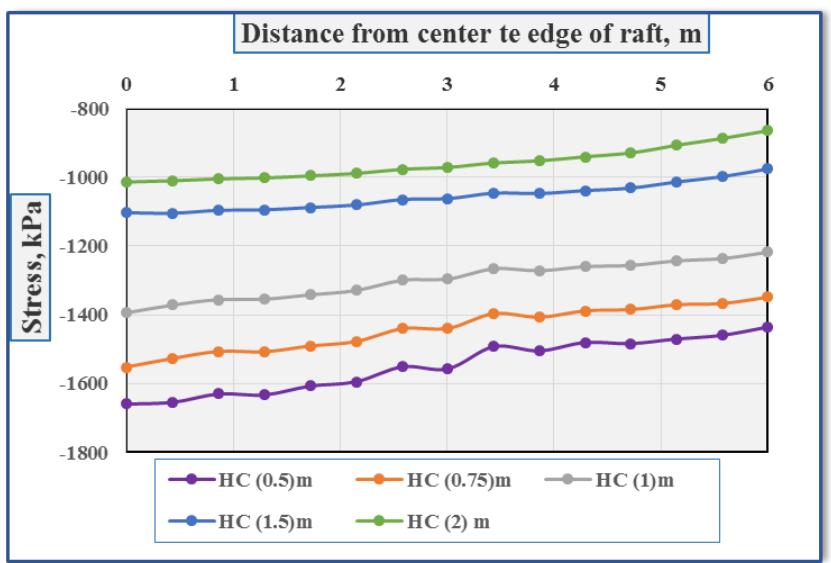

Figure 9: Variation of the axial stress along the centreline of the raft with the cushion thickness.

Table 2: Comparison between axial stress with the cushion thickness.

\begin{tabular}{|c|c|c|}
\hline Description of foundation & Location of pile & $\begin{array}{l}\text { Stress at the top of } \\
\text { The centre pile (kPa) }\end{array}$ \\
\hline \multirow[b]{2}{*}{ Connected pile raft } & Center pile & 1085 \\
\hline & Edge pile & 2237 \\
\hline & Corner pile & 4224 \\
\hline & Center pile & 1202 \\
\hline $\mathrm{HC}(0.5) \mathrm{m}$ & Edge pile & 1993 \\
\hline$\stackrel{\pi}{0}$ & Corner pile & 2074 \\
\hline $\bar{a}$ & Center pile & 1194 \\
\hline $\mathrm{HC}(0.75) \mathrm{m}$ & Edge pile & 1425 \\
\hline $\mathscr{\Xi}$ & Corner pile & 2072 \\
\hline 8 & Center pile & 1447 \\
\hline $\mathrm{HC}(1) \mathrm{m}$ & Edge pile & 1842 \\
\hline & Corner pile & 2239 \\
\hline
\end{tabular}

Table 3: Variation of the load sharing ratio of the unconnected piled raft with the cushion thickness

\begin{tabular}{|c|c|c|c|}
\hline \multicolumn{2}{|c|}{ Description of foundation } & \multicolumn{2}{|c|}{ Load sharing ratio } \\
\hline & & Pile & Raft \\
\hline \multicolumn{2}{|c|}{ Connected piled raft } & 0.66 & 0.34 \\
\hline \multirow{5}{*}{ 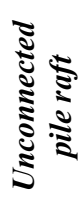 } & $\mathrm{HC}(0.5) \mathrm{m}$ & 0.54 & 0.46 \\
\hline & $\mathrm{HC}(0.75) \mathrm{m}$ & 0.57 & 0.43 \\
\hline & $\mathrm{HC}(1) \mathrm{m}$ & 0.62 & 0.38 \\
\hline & $\mathrm{HC}(1.5) \mathrm{m}$ & 0.70 & 0.30 \\
\hline & $\mathrm{HC}(2) \mathrm{m}$ & 0.72 & 0.27 \\
\hline
\end{tabular}

$\mathrm{HC}=$ cushion thickness.

\section{Conclusions}

1) The total settlement of the connected piled has been lowered by $37 \% \mathrm{wWhen}$ compared with the conventional pile group system, although the total settlement of the unconnected piled has been lowered by $45 \%$.

2) The axial stress in the connected piled raft rises at the pile head and then gradually decreases along the length of the pile. The full axial load is shifted down to a certain length below the pile head in the unconnected system (approximately two meters in the studied model). The axial stress in the pile begins to decrease after the top two meters, in the following depths, the results were similar to that of the connected system.

3) The cushion's thickness has an effect on load distribution between the cushion and the piles. As the cushion thickness increases, the axial stress at the pile head reduces.

Author contribution

\section{Funding}

All authors contributed equally to this work.

This research received no specific grant from any funding agency in the public, commercial, or not-for-profit sectors. 


\section{Data availability statement}

The data that support the findings of this study are available on request from the corresponding author.

Conflicts of interest

The authors declare that there is no conflict of interest.

\section{References}

[1] J. B. Burland, B. B. Broms, and V. F. B. de Mello, Behaviour of foundations and structures, Proc. Int. Conf. Soil Mech. Found. Eng. Tokyo, Japan. July 10-15(1977) 495-536.

[2] G. M. Zhuang and I. K. Lee, An elastic analysis of load distribution for raft-pile systems,Finite Elem. Anal. Des., 18 (1994)259-272. https://doi.org/10.1016/0168-874X(94)90106-6

[3] M. Y. Fattah, M. J. Al-Mosawi, A. A. OO. Al-Zayadi, A. A. O., Time Dependent Behavior of Piled Raft Foundation in Clayey Soil, Geomech. Eng., 5(2013)17-36 . https://doi.org/10.12989/gae.2013.5.1.017

[4] M. Y. Fattah, M. J. Al-Mosawi, A. A. O. Al-Zayadi, Contribution to Long Term Performance of Piled Raft Foundation in Clayey Soil, Int. J. Civ. Eng., 5(2014)130-148.

[5] X. D. Cao, I. H. Wong, and M.-F. Chang, Behavior of model rafts resting on pile-reinforced sand, J. Geotech. Geoenvironmental. Eng., 130(2004)129-138. https://doi.org/10.1061/(ASCE)1090-0241(2004)130:2(129)

[6] I. H. Wong, M. F. Chang, and X. D. Cao, 17. Raft foundations with disconnected settlement-reducing piles, in Design applications of raft foundations, 469-486. https://doi.org/10.1680/daorf.27657.0017

[7] F. Y. Liang, L. Z. Chen, and X. G. Shi, Numerical analysis of composite piled raft with cushion subjected to vertical load, Comput. Geotech., 30(2003)443-453. https://doi.org/10.1016/S0266-352X (03)00057-0

[8] Y.-K. Seo, H.-J. Lee, and T.-H. Kim, Numerical analysis of piled-raft foundation considering sand cushion effects, 2006.

[9] A. Eslami and S. S. Malekshah, Analysis of non-connected piled raft foundations (NCPRF) with cushion by finite element method. Comput. Methods Civ. Eng., 2, 2011.

[10] V. J. Sharma, S. A. Vasanvala, and C. H. Solanki, Behaviour of Cushioned Composite Piled Raft Foundation under Lateral Forces, Indian. Geotech. J., 45(2015). https://doi.org/10.1007/s40098-014-0110-X.

[11] H. H. Karim, M. R. Al-Qaissy, M. K. Hameedi, Numerical Analysis of Piled Raft Foundation on Clayey Soil, Eng. Technol. J., 31(2013)1297-1312.

[12] A. M. J. Alhassani and A. N. Aljorany, Parametric Study on Unconnected Piled Raft Foundation Using Numerical Modelling, J. Eng., 26(2020)156-171. 2020. https://doi.org/10.31026/j.eng.2020.05.11

[13] D. H. Hadi, M. Y. Fattah, M. Q. Whaheed, Effect of Number of Piles on the Behavior of Piled Raft Foundation , Eng. Technol. J., 39(2021)1080-1091 . https://doi.org/10.30684/etj.v39i7.1795

[14] M. R. Mahmood, S. F. A. Al-Wakel, A. A. Hani, Experimental and Numerical Analysis of Piled Raft Foundation Embedded within Partially Saturated Soil , Eng. Technol. J., 35(2017)97-105. https://doi.org/10.30684/etj.35.2A.1 